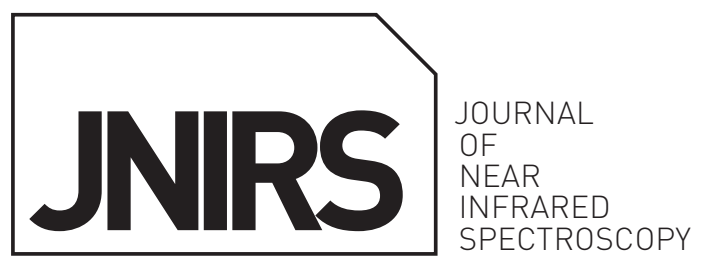

Special Issue: Near Infrared Spectroscopy of Soil

\title{
Visible and near infrared spectra of Ferralsols according to their structural features
}

\author{
José Francirlei de Oliveira, ${ }^{a *}$ Michel Brossard, ${ }^{b}$ Edemar Joaquim Corazza, ${ }^{\mathrm{c}}$ Robélio Leandro Marchão ${ }^{\mathrm{d}}$ and \\ Maria de Fátima Guimarães ${ }^{a}$ \\ anniversidade Estadual de Londrina (UEL), Centro de Ciências Agrárias (CCA), Departamento de Agronomia, Rodovia Celso Garcia Cid, PR 445, \\ Km 380, CEP 86051-980, Londrina,PR, Brazil. E-mail: jfoliveira79@gmail.com

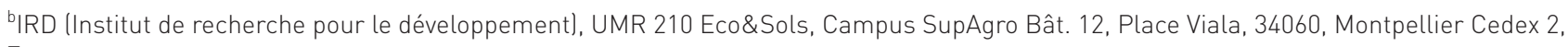 \\ France \\ ‘Embrapa Informação Tecnológica, CP-040315, CEP 70770-901, Brasília, DF, Brazil \\ ¿Embrapa Cerrados, CP-08223, CEP-73310-970, Planaltina, DF, Brazil
}

\begin{abstract}
In soil science, structural features of soils are an important attribute; soils can be characterised by proportional size distribution of aggregates and the pore space between and within those aggregates. The objective of this study was to evaluate the relationship between the visible and near infrared (Vis-NIR) spectra and microaggregates from a collection of Ferralsols. Our dataset consists of 56 spectra from seven soil profiles of kaolinitic and oxidic-gibbsitic Ferralsols. Soils were characterised according to their morphological features: those with a typical porous massive structure and those with a cohesive massive structure. Size distribution of five classes of microaggregate was determined $(1000-2000 \mu \mathrm{m}, 500-1000 \mu \mathrm{m}, 250-500 \mu \mathrm{m}, 105-250 \mu \mathrm{m}$ and $<105 \mu \mathrm{m})$. From the soil spectra, we determined the CIE (Commission Internationale de l'Eclairage) red index $\left(R I_{\mathrm{CIE}}\right)$ and the absorption intensities of kaolinite $\left(I_{\mathrm{Ka}}\right)$ and gibbsite $\left(I_{G b}\right)$. The predominant fraction of microaggregates exhibited sizes between 250 and $1000 \mu \mathrm{m}\left(\Phi_{250-1000}\right)$. The proportional increase of this microaggregate class in the soils increased the scattering and variability of reflected light, particularly when soil samples showed more than $0.50 \mathrm{~g} \mathrm{~g}^{-1}$ of $\Phi_{250-1000}$. The microaggregate size explained over $55 \%$ of reflectance intensity variability of wavelengths in the Vis-NIR regions, principally on reflectance intensity and concavity of the spectra at $436 \mathrm{~nm}, 546 \mathrm{~nm}$ and $2236 \mathrm{~nm}$, which decreases with increased proportion of $\Phi_{250-1000}$. Thus, different structural features of Ferralsols can be directly evaluated through Vis-NIR spectroscopy, even in samples sieved through $2.00 \mathrm{~mm}$. These results highlight the potential use of Vis-NIR spectroscopy in studies of soil classification, soil physical behaviour and soil physical fertility and environmental studies, principally by a new method of analysing bulk density and structure of soil directly from the soil spectra, without the need for predictive models. As well as spectra, $R I_{\mathrm{CIE}}, I_{\mathrm{Ka}}$ and $I_{\mathrm{Gb}}$ can be used to characterise the various structural features of Ferralsols.
\end{abstract}

Keywords: diffuse reflectance spectroscopy, Latosol, soil structure, microped, soil mineral

\section{Introduction}

Diffuse reflectance spectroscopy in the visible and near infrared (Vis-NIR) has been widely used in soil science, particularly during the last two decades. ${ }^{1-3}$ In the first Vis-NIR studies, several pre-treatments were applied to obtain representative spectra of soils, including the sieving of samples to reduce the particle size effect. Thus, the collection of spectra 
in the Vis-NIR region was performed using samples with sizes of less than $2 \mu \mathrm{m}$, with diameters smaller than the wavelength involved in the analysis. ${ }^{1}$ However, due to the evolution of computers and spectrometers and to the important contribution of Norris and Hart ${ }^{4}$ and Ben-Gera and Norris, ${ }^{5}$ the collection of soil spectra is able to be performed on samples sieved at $2000 \mu \mathrm{m}$, without any other pre-treatment.

Soil contains solid particles that differ in size; soil science classifies three principal classes of particles: sand $(0.05-2 \mathrm{~mm})$, silt $(0.002-0.05 \mathrm{~mm})$ and clay $(<0.002 \mathrm{~mm})$. These particles are usually bound together as structural units called microaggregates, aggregates or peds according to their size. Among soils that present a microaggregated structure, there are Ferralsols, ${ }^{6}$ Latosols of the Brazilian soil classification. ${ }^{7}$ They typically have a strong microstructure. 8.9 Microaggregates are near spherical, usually ranging from $80 \mu \mathrm{m}$ to $1000 \mu \mathrm{m}$ in size. They correspond to the "pseudosand", "micropeds" and "granules" previously described by Kubiena, ${ }^{10}$ Brewer ${ }^{11}$ and Trapnell and Webster, ${ }^{12}$ respectively. The size, development and arrangement of these aggregates and the distribution of pore space between and within the aggregates characterise soil structure. As far as soil structural differentiation is concerned, Ferralsols show a B horizon characterised by a moderate to weak macrostructure and a strongly developed granular fine to very fine microstructure..$^{13}$ The organisation and stability of Ferralsol microaggregates are dependent on the concentration of resistant minerals (e.g. quartz), along with principally iron and aluminium oxides and kaolinite. ${ }^{6}$ This mineralogy explains the shape, features and stable microstructure. Soil colour is defined by the proportion of iron oxides, yellowish with goethite or reddish with hematite, according to the organic matter content. The oxidic Ferralsols are organised into microaggregates of less than $1 \mathrm{~mm}$ in size, with in situ porous massive macromorphological characteristics, and kaolinitic Ferralsols are organised into nodules surrounded by a dense and continuous plasma with cohesive massive macromorphological characteristics. ${ }^{14}$ Volland-Tuduri ${ }^{15}$ noted that Ferralsols might exhibit up to four types of microaggregate, with diameters that vary from $50 \mu \mathrm{m}$ to $500 \mu \mathrm{m}$, promoting significant variations in inter-and intra-aggregate porosity according to their proportions, as also observed by Balbino et al. ${ }^{16}$

Reflectance obtained by satellite images or by laboratory equipment is inversely proportional to the particle diameter and microroughness of a sample. 1,17-19 Reflectance values depend on soil aggregates and how they are organised to form the structure, which is characterised by its millimetric roughness, directly influencing the scattering of light in the spectrometer. ${ }^{3,8-10}$ Additionally, Chang et al. ${ }^{20}$ observed an accuracy of Vis-NIR spectra in samples with similar particle sizes. Using samples of four soil types, including a red Ferralsol, Wu et al. ${ }^{18}$ observed that sample size and roughness changed the region of spectral peaks, particularly those near the $2350 \mathrm{~nm}$ region. Chamizo et al. ${ }^{21}$ observed that diffuse reflectance spectroscopy discriminated soil biological aggregates and Croft et al. ${ }^{22}$ reported that it was possible to characterise the roughness of different soil samples with spectra from the $400-2500 \mathrm{~nm}$ region. In the NIR region it was possible to distinguish aggregates according to their origin, soil, eroded material and biological aggregates. ${ }^{23}$ In this way, different Ferralsols may promote a specific light variability for each soil macromorphology. This is because the shapes and features of microaggregates associated with organic matter and iron and aluminium oxy-hydroxides significantly affect wavelengths in the visible region, especially at $700 \mathrm{~nm}$, $546 \mathrm{~nm}$ and $436 \mathrm{~nm}$ that represent the balance between red, green and blue colours (spectral bands known as red index of soil, R/CIE l, and $2200 \mathrm{~nm}$ and $2300 \mathrm{~nm}$ which are strongly linked to the absorption intensity of kaolinite and gibbsite, respectively. These facts explain why the relations between soil colour and spectra have been studied in the last fifty years. ${ }^{24-26}$

Macromorphological soil features are important for soil classification, soil physical behaviour, soil physical fertility and environmental studies. We consider that different macromorphological features may promote diverse spectra according to the shapes and features of the aggregates. This effect has not been investigated in natural microaggregates and the link between the spectra and existing microaggregates in soil samples sieved at $2000 \mu \mathrm{m}$ is not clear. Therefore, the objective of this study was to evaluate the Vis-NIR spectra of soil in relation to microaggregates from a collection of Ferralsols with various mineralogy.

\section{Materials and methods Sample collection and soil characterisation}

Seven Ferralsol profiles developed on meta-sedimentary rock composed of mudstones were collected from the central plateau, Brazil (Goiás state, $15^{\circ} 22^{\prime}$ S and $47^{\circ} 27^{\prime} \mathrm{W}$ ) and used in the present study. The soils were classified according to the Brazilian soil classification system ${ }^{7}$ as Acric Red-Yellow Latosol, Dystrophic Red Latosol, Alic Red-Yellow Latosol and Dystrophic Red-Yellow Latosol (Table 1). Soils were described according to the field manual of Santos et al. ${ }^{27}$ and the colour of the dry soil was determined using the Munsell chart ${ }^{28}$ as reported previously. ${ }^{29}$

All samples were collected in triplicate from soil profiles at the following depths: $0.00-0.05 \mathrm{~m}, 0.05-0.10 \mathrm{~m}, 0.125-0.175 \mathrm{~m}$, $0.225-0.275 \mathrm{~m}, 0.325-0.375 \mathrm{~m}, 0.725-0.775 \mathrm{~m}, 0.875-0.925 \mathrm{~m}$ and $1.075-1.125 \mathrm{~m}$. The disturbed samples were air-dried and sieved at $2 \mathrm{~mm}$. All samples exhibited 100\% fine earth.

The physical and chemical analyses of samples were performed according to Donagema et al. ${ }^{30}$ In brief, soil bulk density was determined by the cylinder method $\left(94.16 \mathrm{~cm}^{3}\right)$; clay fraction was determined by the pipette method using $1 \mathrm{~N}$ $\mathrm{NaOH}$ as a chemical dispersant; organic matter content was determined by the Walkley-Black method; silica $\left(\mathrm{SiO}_{2}\right)$, iron $\left(\mathrm{Fe}_{2} \mathrm{O}_{3}\right)$, aluminium $\left(\mathrm{Al}_{2} \mathrm{O}_{3}\right)$ and titanium $\left(\mathrm{TiO}_{2}\right)$ were extracted by the sulphuric acid digestion method after dissolution in 1:1 


\begin{tabular}{|c|c|c|c|c|c|c|c|c|c|c|c|c|c|c|}
\hline ' & 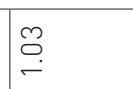 & 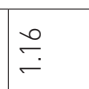 & סִ & \begin{tabular}{|l|}
$\alpha$ \\
$\alpha$ \\
$\sigma$ \\
0
\end{tabular} & $\begin{array}{l}m \\
2 \\
0 \\
0\end{array}$ & $\begin{array}{l}0 \\
\infty \\
\infty \\
0\end{array}$ & $\stackrel{\circ}{\circ}$ & $\stackrel{\stackrel{a}{\circ}}{\stackrel{-}{*}}$ & $\stackrel{尺}{\stackrel{2}{0}}$ & \begin{tabular}{|l|}
\multirow{q}{q}{} \\
ó
\end{tabular} & $\begin{array}{c}\bar{\alpha} \\
\dot{\alpha} \\
\alpha\end{array}$ & 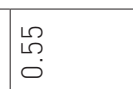 & $\stackrel{\gtrless}{\stackrel{\sim}{=}}$ & $\underset{\sim}{\stackrel{\sim}{\Xi}}$ \\
\hline צ' & $\stackrel{m}{-}$ & $\begin{array}{l}\infty \\
\stackrel{\infty}{+} \\
-\end{array}$ & $\begin{array}{l} \\
\stackrel{2}{0} \\
0\end{array}$ & $\underset{\sim}{\sim}$ & $\cong$ & $\stackrel{\circ}{\circ}$ & $\stackrel{\stackrel{\sim}{\sim}}{\rightleftharpoons}$ & $\underset{\sim}{\stackrel{N}{\sim}}$ & $\begin{array}{l} \\
\text { Do } \\
0 \\
0\end{array}$ & $\begin{array}{l}\infty \\
\stackrel{\infty}{\infty} \\
0 \\
0\end{array}$ & $\stackrel{\sim}{-}$ & $\bar{\Sigma}$ & $\stackrel{\sim}{\sim}$ & $\stackrel{\substack{f \\
\sim}}{-}$ \\
\hline 票 & $\stackrel{\curvearrowright}{\curvearrowright}$ & œ & $\bar{\checkmark}$ & 㐫 & $=$ & $=$ & $=$ & $\stackrel{m}{2}$ & $\simeq$ & 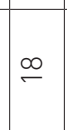 & $\approx$ & $\stackrel{\circ}{=}$ & $\stackrel{\circ}{=}$ & $\gtrsim$ \\
\hline 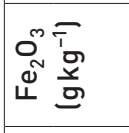 & $\Phi$ & $\stackrel{ }{\rightleftharpoons}$ & م & $\stackrel{L}{\alpha}$ & 寸 & $\underset{\checkmark}{\Im}$ & 守 & \& & م & $\approx$ & $\curvearrowright$ & $\infty$ & $\bar{\forall}$ & 앙 \\
\hline 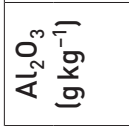 & 足 & 요 & $\stackrel{\stackrel{\infty}{\infty}}{\sim}$ & $\stackrel{\stackrel{\infty}{~}}{\curvearrowright}$ & $\stackrel{p}{\dddot{m}}$ & 肙 & 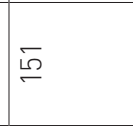 & $\stackrel{\infty}{=}$ & $\cong$ & $\stackrel{\circ}{\sim}$ & $\stackrel{\stackrel{\sim}{\sim}}{\sim}$ & $\stackrel{\ominus}{\sim}$ & $\stackrel{\alpha}{\varrho}$ & 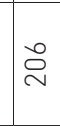 \\
\hline 㱐 & $\stackrel{\stackrel{\perp}{\infty}}{\propto}$ & $\stackrel{\sim}{N}$ & $\stackrel{\stackrel{\sim}{\simeq}}{\simeq}$ & $\stackrel{\circ}{\rightleftharpoons}$ & $\infty$ & $\infty$ & $\Xi$ & $\stackrel{\infty}{\simeq}$ & $\stackrel{\llcorner}{\infty}$ & $\approx$ & 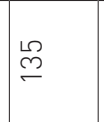 & $\begin{array}{l}\infty \\
\infty\end{array}$ & $\stackrel{\llcorner}{\stackrel{\circ}{\circ}}$ & 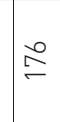 \\
\hline 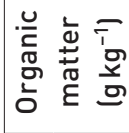 & 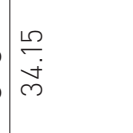 & $\begin{array}{l}\infty \\
\infty \\
\infty \\
\infty \\
\infty\end{array}$ & $\underset{\sim}{\bar{\infty}}$ & $\underset{\stackrel{\sim}{\sim}}{\stackrel{\sim}{\sim}}$ & 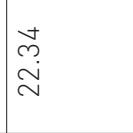 & $\begin{array}{l}\alpha \\
\text { m. } \\
\text { p. }\end{array}$ & $\begin{array}{l}\infty \\
\infty \\
\sim \\
\sim \\
\sim\end{array}$ & 导 & $\begin{array}{l}\text { d } \\
\infty \\
\stackrel{d}{\sim}\end{array}$ & \begin{tabular}{l}
\multirow{y}{y}{} \\
0 \\
0
\end{tabular} & $\begin{array}{l}\stackrel{\rho}{\alpha} \\
\stackrel{\alpha}{\sigma}\end{array}$ & 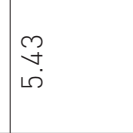 & $\begin{array}{l}\bar{N} \\
\stackrel{\rho}{\infty}\end{array}$ & 色 \\
\hline 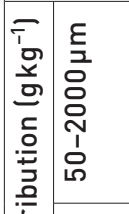 & $\stackrel{\infty}{\infty}$ & $\hat{y}$ & $\stackrel{\infty}{\subseteq}$ & \& & 勇 & 웅 & $\underset{\checkmark}{\stackrel{\sigma}{\checkmark}}$ & $\stackrel{\infty}{\underset{\Im}{\Im}}$ & 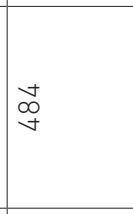 & $\mid \begin{array}{l}a \\
\dot{0} \\
\dot{y}\end{array}$ & $\stackrel{\stackrel{D}{\sim}}{\sim}$ & ○ & $\underset{\sim}{\stackrel{a}{d}}$ & $\bar{\sigma}$ \\
\hline 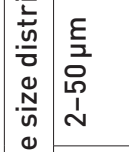 & ब & 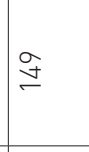 & $\infty$ & $\tilde{ల}$ & $\stackrel{\curvearrowright}{\simeq}$ & $\stackrel{a}{\underline{m}}$ & $\stackrel{\circ}{\circ}$ & $\cong$ & \begin{tabular}{l}
$\infty$ \\
\hdashline \\
\hdashline
\end{tabular} & $\stackrel{\infty}{=}$ & $\stackrel{ }{\circ}$ & $\stackrel{\infty}{\sim}$ & 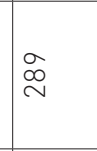 & $\underset{\curvearrowright}{\mathfrak{q}}$ \\
\hline 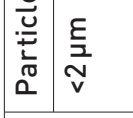 & 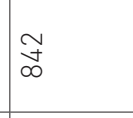 & $\widetilde{\widetilde{O}}$ & $\frac{\sqrt{2}}{2}$ & \begin{tabular}{|l|}
$\infty$ \\
$\infty$ \\
$\infty$
\end{tabular} & 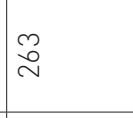 & $\stackrel{\llcorner}{\stackrel{\sim}{\sim}}$ & 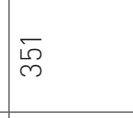 & $\stackrel{\hat{\alpha}}{\mathrm{m}}$ & $\underset{\text { \} }{\stackrel{\checkmark}{+}}} &{\text { ôे }} &{\text { 㖞 }} &{\text { ఫ }} &{\begin{array}{l}\underset{N}{0} \\
\multirow{\sigma}{*}{}\end{array}} &{\underset{\text { ¿n }}{2}} \\
{\hline \text { 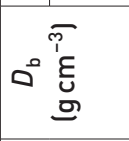 }} &{\begin{array}{l}\bar{\alpha} \\
\sigma \\
\delta\end{array}} &{\begin{array}{l}\infty \\
\infty \\
\infty \\
0 \\
0\end{array}} &{\begin{array}{l}\infty \\
\infty \\
\infty \\
0\end{array}} &{\mid \begin{array}{c}\infty \\
\infty \\
0 \\
0\end{array}} &{\stackrel{+}{\stackrel{\sim}{=}}} &{\stackrel{m}{=}} &{\stackrel{\circ}{\circ}} &{\begin{array}{l}\stackrel{2}{2} \\
\alpha \\
0\end{array}} &{\stackrel{t}{\stackrel{\Xi}{-}}} &{\stackrel{\leftrightarrow}{\stackrel{2}{\circ}}} &{\stackrel{ \pm}{\rightleftarrows}} &{\stackrel{\infty}{\stackrel{一}{-}}} &{\stackrel{\searrow}{\stackrel{\sim}{=}}} &{\stackrel{\sigma}{-}} \\
{\hline \text { 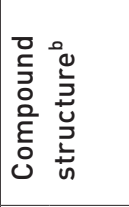 }} &{\text { 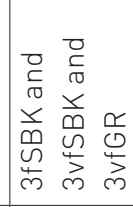 }} &{\text { 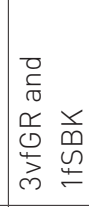 }} &{\text { 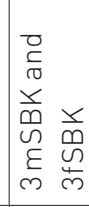 }} &{\begin{array}{|l} \\
\frac{1}{0} \\
\frac{0}{3} \\
m\end{array}} &{\text { 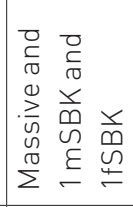 }} &{\text { 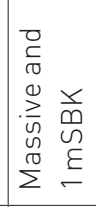 }} &{\text { 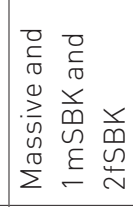 }} &{\text { 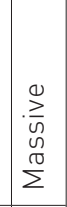 }} &{\text { 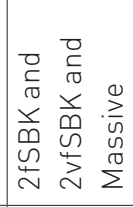 }} &{\text { 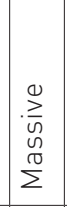 }} &{\text { 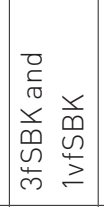 }} &{\text { 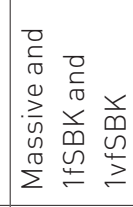 }} &{\text { 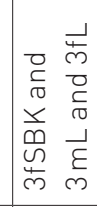 }} &{\text { 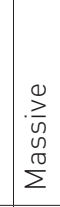 }} \\
{\hline \text { 产 }} &{\begin{array}{l}0 \\
\multirow{2}{*}{} \\
\frac{1}{2} \\
2 \\
\llcorner\end{array}} &{\text { 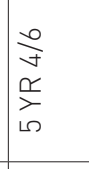 }} &{\begin{array}{l}\frac{1}{2} \\
m \\
\frac{1}{2} \\
\nu \\
n\end{array}} &{\begin{array}{|l|}\infty \\
\dot{y} \\
\tilde{y} \\
\Sigma \\
\llcorner \\
\sim \\
\sim \\
\end{array}} &{\text { 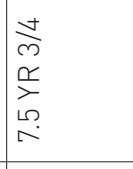 }} &{\begin{array}{l}\frac{ \pm}{m} \\
\frac{\pi}{2} \\
\frac{\pi}{20}\end{array}} &{\begin{array}{l}\frac{N}{m} \\
\frac{\pi}{2} \\
\frac{N}{\nu} \\
\llcorner\end{array}} &{\text { 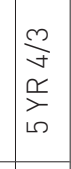 }} &{\begin{array}{l}\frac{m}{\infty} \\
\infty \\
\frac{1}{2} \\
\llcorner \\
\llcorner\end{array}} &{\text { 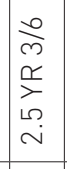 }} &{\text { 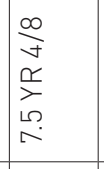 }} &{\text { 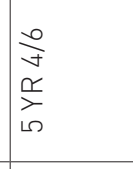 }} &{\text { 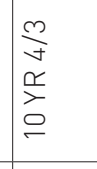 }} &{\text { 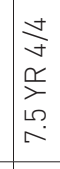 }} \\
{\hline \text { 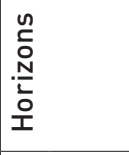 }} &{\text { 还 }} &{\bar{\aleph}} &{\text { 这 }} &{\text { 官 }} &{\text { \& }} &{\text { 岗 }} &{\text { \& }} &{\text { 玄 }} &{\text { 足 }} &{\begin{array}{l}3 \\
0 \\
0\end{array}} &{\text { 里 }} &{\overline{3}} &{\text { \& }} &{\text { 芯 }} \\
{\hline \text { 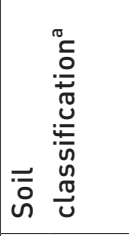 }} &{\text { 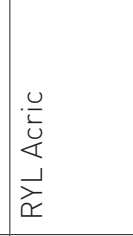 }} &{ } &{\text { 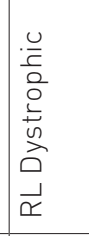 }} &{ } &{\text { 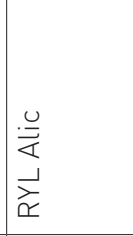 }} &{ } &{\text { 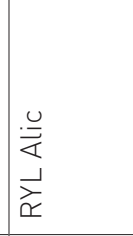 }} &{ } &{\text { 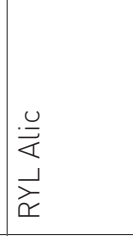 }} &{ } &{\text { 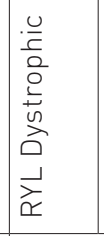 }} &{ } &{\text { 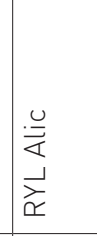 }} &{ } \\
{\hline \text { : }} &{\Xi} &{ } &{ \pm} &{ } &{\text { ـ }} &{ } &{\lrcorner} &{ } &{\stackrel{\infty}{\lrcorner}} &{ } &{\text { 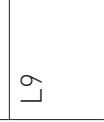 }} &{ } &{\bar{\Xi}} &{ } \\
$\hline
\end{tabular}

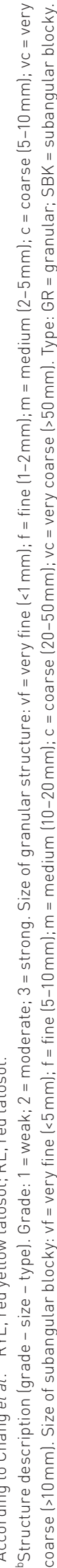


$\mathrm{H}_{2} \mathrm{SO}_{4}$; and silica, iron, aluminium and titanium contents were determined by inductively coupled plasma spectrometry. Silica and aluminium contents were used to calculate kaolinite and gibbsite contents, assuming that no isomorphic substitution occurs in these minerals. ${ }^{31}$ To calculate the goethite and hematite contents, $33 \%$ and $16 \%$ aluminium substitutions were assumed, respectively. ${ }^{32}$

The $\mathrm{SiO}_{2}, \mathrm{Fe}_{2} \mathrm{O}_{3}$ and $\mathrm{Al}_{2} \mathrm{O}_{3}$ contents, which were determined after extraction with sulphuric acid, were used to calculate the $K_{i}$ and $K_{r}$ ratios as follows: ${ }^{33}$

$$
\begin{gathered}
K_{\mathrm{i}}=\frac{\left(\mathrm{SiO}_{2}\right) / 60}{\left(\mathrm{Al}_{2} \mathrm{O}_{3}\right) / 102}=1.7 \times \frac{\mathrm{SiO}_{2}}{\mathrm{Al}_{2} \mathrm{O}_{3}} \\
K_{r}=\frac{\left(\mathrm{SiO}_{2}\right) / 60}{\left[\left(\mathrm{Al}_{2} \mathrm{O}_{3}\right) / 102\right]+\left[\left(\mathrm{Fe}_{2} \mathrm{O}_{3}\right) / 160\right]}=1.7 \times \frac{\mathrm{SiO}_{2}}{\left(\mathrm{Al}_{2} \mathrm{O}_{3}\right)+0.6375\left(\mathrm{Fe}_{2} \mathrm{O}_{3}\right)}
\end{gathered}
$$

\section{Fractionation of microaggregates in air-dried soil samples}

Particle-size fractionation of microaggregates of $<2000 \mu \mathrm{m}$ was carried out using samples from the $0.875-0.925 \mathrm{~m}$ layer of seven profiles: L1, L4, L5, L7, L8, L9 and L1129 (Table 1).

After reproducibility tests, air-dried soil samples $130 \mathrm{~g}$; $<2000 \mu \mathrm{m}$ ) were sieved through 2.00, 1.00, 0.50, 0.25 and $0.105 \mathrm{~mm}$ sieves for $30 \mathrm{~s}$ with mechanical agitation in a horizontal position, according to Volland-Tuduri. ${ }^{15}$ After correcting for water contents $\left(105^{\circ} \mathrm{C}\right)$, the $1000-2000 \mu \mathrm{m}, 500-1000 \mu \mathrm{m}$, 250-500 $\mu \mathrm{m}, 105-250 \mu \mathrm{m}$ and $<105 \mu \mathrm{m}$ particle-size classes were determined. A linear equation based on the relation between $\Phi$, greater proportion of microaggregates, and the inverse bulk density was generated, taking into account the relationship between macro- and microaggregates proposed by Volland-Tuduri et al. ${ }^{34}$ (Figure 1).

This equation $\left(\Phi_{250-1000}=0.608\left(1 / D_{b}\right)-0.113\right)$ was used to determine parameter $\Phi$ for the other seven soil depths:

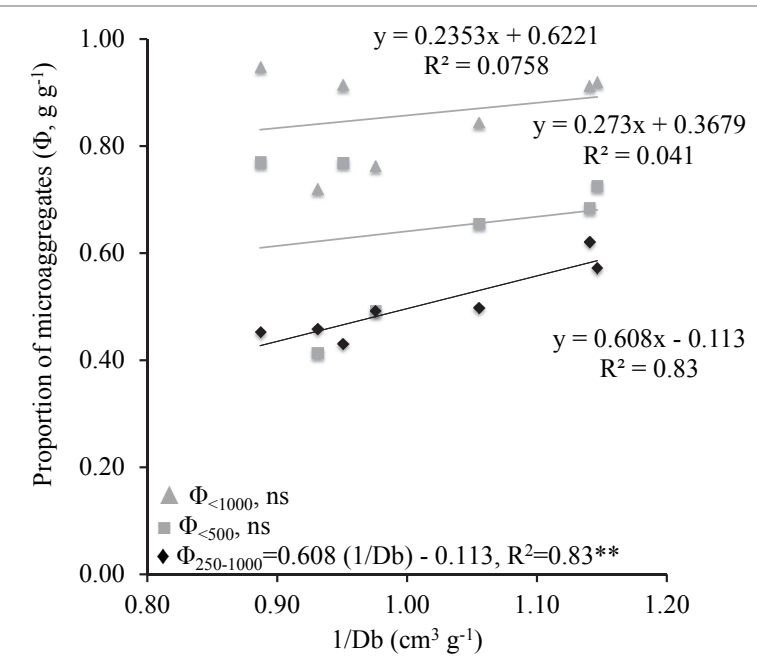

Figure 1. Correlation between the reciprocal of soil bulk density and the mass proportion of microaggregates with size $<1000 \mu \mathrm{m}\left(\Phi_{<1000}\right),<500 \mu \mathrm{m}\left(\Phi_{<500}\right)$ and $250-1000 \mu \mathrm{m}\left(\Phi_{250-1000}\right.$, $n=7)$ fraction. ns, non-significant correlation ( $p<0.05$ ).
$0.00-0.05 \mathrm{~m}, 0.05-0.10 \mathrm{~m}, 0.125-0.175 \mathrm{~m}, 0.225-0.275 \mathrm{~m}$, $0.325-0.375 \mathrm{~m}, 0.725-0.775 \mathrm{~m}$ and $1.075-1.125 \mathrm{~m}(n=56)$.

\section{Vis-NIR analyses}

Sample preparation and spectra collection

Spectra were collected from $5 \mathrm{~g}$ of each soil sample $(<2000 \mu \mathrm{m}$ samples from the eight layers of soil profiles) packed into a cup with a $0.05 \mathrm{~m}$ diameter quartz lens; the samples were previously dried at $40^{\circ} \mathrm{C}$ for $24 \mathrm{~h}$ and maintained in desiccators until the time of collection of the spectra to standardise their water content. Reflectance was determined at $2 \mathrm{~nm}$ intervals in the Vis-NIR region between $400 \mathrm{~nm}$ and $2500 \mathrm{~nm}$ using a FOSS XDS near infrared rapid content analyser (www.foss.dk), resulting in 1050 points for spectra.

The spectral variability was evaluated by repeating measurements 30 times on one soil sample, which was randomly selected. To perform each new scan, the ring cup was removed from the equipment and a new sample was prepared for the next replicate. The reflectance amplitudes of these readings ranged from $0.008 \mathrm{~nm}$ to $0.01 \mathrm{~nm}$ ( $95 \%$ probability). Therefore, variations larger than $0.01 \mathrm{~nm}$ between the spectra of different soil profiles were considered to be due to the sample, and no residual effect due to the equipment was observed. Each spectrum sample represented an average of 32 readings. The average spectrum from three repetitions for each layer of the soil profiles was obtained using WinISI II v1.50 software (Foss NIRSystems/Tecator Infrasoft International LLC, Silver Spring, MD, USA).

\section{Spectral attributes}

According to the CIE (Commission Internationale de l'Eclairage) the red index $\left(R I_{\mathrm{CIE}}\right)$ considers the wavelengths $700 \mathrm{~nm}$ for red $(R), 546 \mathrm{~nm}$ for green (G) and $436 \mathrm{~nm}$ for blue (B) to represent the visible spectrum region. This colorimetric parameter, which is derived from the diffuse reflectance, is related to the hematite content and to the hematite/goethite ratio in the soil. ${ }^{24,25} R / \mathrm{CIE}$ was calculated according to the following equation:

$$
R I_{\mathrm{CIE}}=\frac{(x-0.32)^{2} \times 10,000}{(y-0.32) \times Y^{2}}
$$

where $x$ and $y$ correspond to the chromaticity coordinates of the Munsell colour chart ${ }^{28}$ and $Y$ to the light intensity based on the standard observer determined by the CIE in 1931, using standard D65 lighting. Chromaticity coordinates were derived from the trichromatic components $(X, Y$ and $Z)$ and calculated according to Madeira Netto. ${ }^{35}$

Absorption intensities of kaolinite and gibbsite were used to analyse the effects of microaggregate grain size classes on the spectra because Madeira Netto et al. ${ }^{36}$ observed that absorption intensities of kaolinite and gibbsite had a better correlation with the spectra than did the contents of these minerals.

The point of maximum reflectance between wavelengths $2200 \mathrm{~nm}$ and $2300 \mathrm{~nm}$ was chosen to calculate the absorption 
intensities of kaolinite $\left(I_{\mathrm{Ka}}\right)$ and gibbsite $\left(I_{G b}\right)^{36}$ using the following equations:

$$
\begin{aligned}
& I_{\mathrm{Ka}}=R_{\max }-R_{2205} \\
& I_{\mathrm{Gb}}=R_{\max }-R_{2265}
\end{aligned}
$$

where $R_{\text {max }}$ is the maximum reflectance between $2205 \mathrm{~nm}$ and $2265 \mathrm{~nm}$, and $R_{2205}$ and $R_{2265}$ are the reflectances at $2205 \mathrm{~nm}$ and $2265 \mathrm{~nm}$, respectively. The ratio between the absorption intensities of these minerals was calculated using the equation $I_{\mathrm{Ka}_{\mathrm{a}}} /\left(I_{\mathrm{Ka}}-I_{\mathrm{Gb}}\right)$.

\section{Statistical analyses}

The effect of the microaggregates on the spectra was assessed using linear regression analyses and the Pearson correlation $(p<0.01)$. To better represent the correlations with the components of the soil, the reflectance $R$ in the correlation matrix was transformed into an absorbance value using the equation $A=\log _{10}(1 / R)$. The $401 \mathrm{~nm}, 436 \mathrm{~nm}$, $440 \mathrm{~nm}, 530 \mathrm{~nm}, 546 \mathrm{~nm}, 550 \mathrm{~nm}, 650 \mathrm{~nm}, 700 \mathrm{~nm}, 845 \mathrm{~nm}$, $850 \mathrm{~nm}, 870 \mathrm{~nm}, 901 \mathrm{~nm}, 931 \mathrm{~nm}, 951 \mathrm{~nm}, 1051 \mathrm{~nm}, 1302 \mathrm{~nm}$, $1401 \mathrm{~nm}, 1903 \mathrm{~nm}, 2201 \mathrm{~nm}, 2236 \mathrm{~nm}, 2263 \mathrm{~nm}, 2300 \mathrm{~nm}$, $2352 \mathrm{~nm}$ and $2430 \mathrm{~nm}$ wavelengths were used in the correlation matrix to confirm the effects of microaggregates on the spectra; significant coefficients greater than $0.5(p<0.05)$ were considered. These wavelengths were selected because of their interactions with phyllosilicates (1:1), iron and aluminium oxy-hydroxides and organic matter $25,26,36,37$ and allowed the discrimination of different soils according to their spectra. $^{38}$

Following their field description, the superficial $10.05-$ $0.10 \mathrm{~m})$ and subsurface $(0.875-0.925 \mathrm{~m})$ layers of the soils were grouped according to their macromorphological descriptions for a comparison of variables related to the proportion of microaggregates characterised by factor $\Phi_{250-1000}$ and to the spectra $\left(R I_{\text {CIE }} I_{K a}\right.$ and $\left.I_{G b}\right)$. The data were subjected to the Kruskal-Wallis test ${ }^{39}$ at $5 \%$ probability.

\section{Results}

\section{Soils studied}

In terms of soil morphology, a subangular block structure on the surface and a strong granular and very thin structure in the layers below $0.72 \mathrm{~m}$ were observed, with in situ porous massive macromorphological characteristics in L1 and $L 4$ profiles and with cohesive massive macromorphological characteristics in L5, L7, L8, L9 and L11 profiles (Table 1).

For the seven soil profiles, the clay content ranged from $263 \mathrm{~g} \mathrm{~kg}^{-1}$ to $878 \mathrm{~g} \mathrm{~kg}^{-1}$, the iron oxide content ranged from $40 \mathrm{~g} \mathrm{~kg}^{-1}$ to $110 \mathrm{~g} \mathrm{~kg}^{-1}$ and the hue ranged from $2.5 \mathrm{YR}$ to $10 \mathrm{YR}$. The $K_{i}$ and $K_{r}$ values of the surface layer were greater than 0.75 for L1, L4, L5, L7 and L11 soils and less than 0.75 for $L 8$ and L9 soils (Table 1).

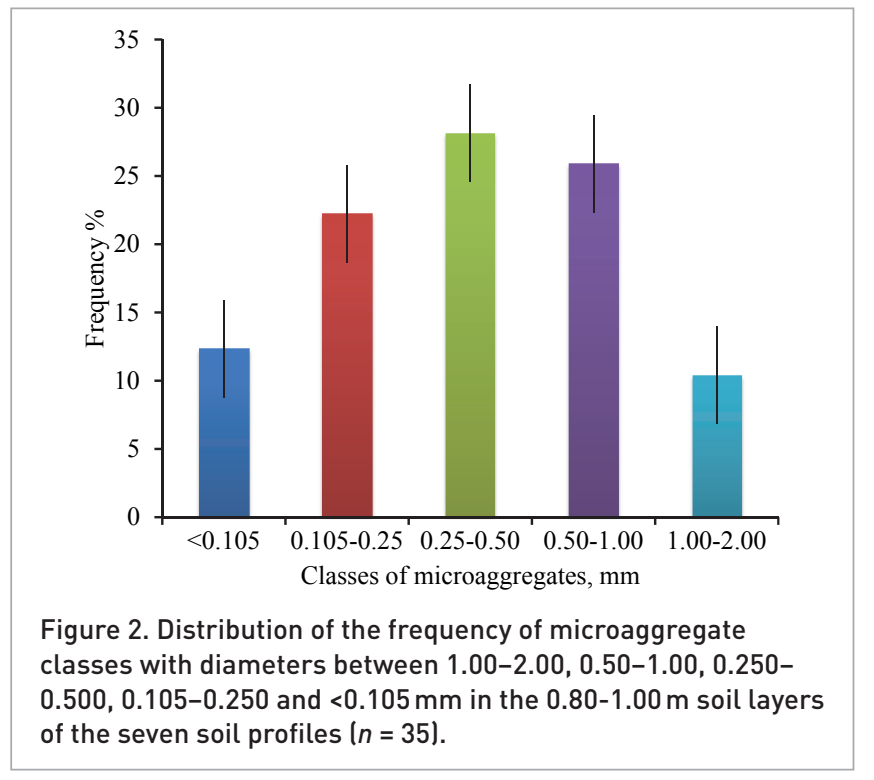

\section{Particle size distribution of microaggregates ( $\Phi$ ]}

The $\Phi$ of the greatest proportion was from the $250-1000 \mu \mathrm{m}$ class $\left(\Phi_{250-1000}\right)$ that varied from $0.38 \mathrm{~g} \mathrm{~g}^{-1}$ to $0.58 \mathrm{~g} \mathrm{~g}^{-1}$ of soil (Figure 2).

L1 and L4 soils, with porous massive structures, exhibited $29 \%$ higher $\Phi_{250-1000}$ on average compared with L5, L7, L8, L9 and L11 soils, which had cohesive massive structures. This difference was significant (Table 2) and confirmed previous macromorphological soil descriptions.

\section{Soil spectra}

The mean spectra of the surface and subsurface layers of the seven soil profiles were described in Oliveira et al. ${ }^{29} \mathrm{~J} . \mathrm{F}$. We observed five bands of reflectance at $400-550 \mathrm{~nm}, 700-850 \mathrm{~nm}$, 1350-1450 nm, 1850-2000 nm and 2200-2300 nm [Figure 3(a)].

We observed that bands of cohesive massive structure profiles (L5, L7, L8, L9 and, especially, L11) from the 0.80 $1.00 \mathrm{~m}$ layer of the seven soils presented a narrow spectral band with greater reflectance intensity than soils L1 and L4 with porous massive structure [Figure 3(b)]. The concavity of the spectral band and the reflectance intensity at wavelengths of $436 \mathrm{~nm}, 546 \mathrm{~nm}$ and $700 \mathrm{~nm}$ were related to the proportion of microaggregates. The increase in proportion of $\Phi_{250-1000}$ was associated with a decrease in the reflectance intensity and an increased concavity of the spectra [Figure 3(b)].

Likewise, it was observed that reflectance intensity between $2200 \mathrm{~nm}$ and $2300 \mathrm{~nm}$ was related to $\Phi_{250-1000}$, given that soils with cohesive massive structure (L5, L7, L8, L9 and, particularly, $L 11)$ presented greater reflectance intensity at $2265 \mathrm{~nm}$ than $L 1$ and L4 soils with porous massive structure [Figure 3(c)].

\section{Relationship between wavelengths and soil morphology}

Soil macromorphology, represented by proportion of $\Phi_{250-}$ 1000 , was correlated with wavelengths between $400 \mathrm{~nm}$ and 
Table 2. Microstructural and spectral characteristics of soil layer surface $(0.05-0.10 \mathrm{~m})$ and subsurface $(0.875-0.925 \mathrm{~m})$, based on morphological structures.

\begin{tabular}{|c|c|c|c|c|c|}
\hline Soil profile & Horizons & $\Phi_{250-1000}\left(\mathrm{~g} \mathrm{~g}^{-1}\right)$ & $R I_{\mathrm{CIE}}$ & $I_{\mathrm{Ka}}$ & $I_{\mathrm{Gb}}$ \\
\hline \multicolumn{6}{|c|}{ Porous massive structure } \\
\hline \multirow[t]{2}{*}{ L1 } & Ap & 0.56 & 0.77 & 0.14 & 0.1 \\
\hline & Bw1 & 0.58 & 1.05 & 0.07 & 0.02 \\
\hline \multirow[t]{2}{*}{ ᄂ4 } & Ap & 0.58 & 1.03 & 0.17 & 0.12 \\
\hline & Bw & 0.58 & 1.44 & 0.12 & 0.05 \\
\hline Mean & & 0.58 & 1.07 & 0.13 & 0.07 \\
\hline CV\% & & 1.74 & 25.75 & 33.63 & 63.08 \\
\hline \multicolumn{6}{|c|}{ Cohesive massive structure } \\
\hline \multirow[t]{2}{*}{ L5 } & Ap & 0.38 & 0.24 & 0.33 & 0.33 \\
\hline & Bw2 & 0.43 & 0.31 & 0.34 & 0.34 \\
\hline \multirow[t]{2}{*}{ L7 } & Ap & 0.46 & 0.52 & 0.31 & 0.32 \\
\hline & Bw1 & 0.53 & 0.62 & 0.31 & 0.32 \\
\hline \multirow[t]{2}{*}{ L8 } & Ap & 0.47 & 0.48 & 0.28 & 0.28 \\
\hline & Bw1 & 0.47 & 0.58 & 0.29 & 0.29 \\
\hline \multirow[t]{2}{*}{ L9 } & Ap & 0.42 & 0.19 & 0.23 & 0.21 \\
\hline & Bw1 & 0.48 & 0.21 & 0.27 & 0.24 \\
\hline \multirow[t]{2}{*}{ L11 } & $A p$ & 0.38 & 0.2 & 0.32 & 0.35 \\
\hline & Bw2 & 0.45 & 0.18 & 0.33 & 0.38 \\
\hline Mean & & 0.45 & 0.35 & 0.30 & 0.31 \\
\hline CV\% & & 10.34 & 50.13 & 11.23 & 16.89 \\
\hline$H$ & & 8.10 & 8.00 & 8.03 & 8.01 \\
\hline$p$-value & & $<0.01$ & $<0.01$ & $<0.01$ & $<0.01$ \\
\hline
\end{tabular}

$2430 \mathrm{~nm}$ (Table 3), except for the $650 \mathrm{~nm}$ and $700 \mathrm{~nm}$ wavelengths. The predominant proportion of microaggregates in these Ferralsols accounted for over $55 \%$ of reflectance variability at wavelengths between $436 \mathrm{~nm}$ and $546 \mathrm{~nm}$ and over $65 \%$ for wavelength of $2236 \mathrm{~nm}$. Reflectance intensity at these wavelengths decreased with an increase in proportion of $\Phi_{250-}$ 1000 [Figure 3(d)-(f)].

Microaggregates were related to $R I_{\mathrm{CIE}}$ and to the absorption intensity of kaolinite and gibbsite (Table 3). L1 and L4 soils, with higher proportions of $\Phi_{250-1000}$, exhibited higher $R$ I CIE values and lower $I_{\mathrm{Ka}}$ and $I_{\mathrm{Gb}}$ values than the cohesive massive structure profiles. These differences were significant (Table 2). In the region of $400 \mathrm{~nm}$ to $730 \mathrm{~nm}$, the increase in proportion of $\Phi_{250-1000}$ intensified the $R /_{\text {CIE }}$ absorption [Figure 4(a)]. Furthermore, in the NIR region in soils with cohesive massive structures, the increase in $\Phi_{250-1000}$ did not result in increased variability of the ratio $I_{\mathrm{Ka}} /\left(I_{\mathrm{Ka}}+I_{\mathrm{Gb}}\right)$, in contrast to the porous massive structure soils whose variability was more obvious [Figure $4(\mathrm{~b})$ ]. Thus, the variability between $I_{\mathrm{Ka}}$ and $I_{\mathrm{Gb}}$ ratio, at wavelengths between $2200 \mathrm{~nm}$ and $2300 \mathrm{~nm}$, increased when $\Phi_{250-1000}$ was greater than $0.50 \mathrm{~g} \mathrm{~g}^{-1}$ of soil.

$R I_{\text {CIE }}$ was negatively related to total iron oxides $\left(R^{2}=-0.55\right.$; $p<0.01)$, in particular with goethite contents $\left(R^{2}=-0.53\right.$; $p<0.01)$, and this relationship occurred throughout the $401-1051 \mathrm{~nm}$ wavelength range $\left(R^{2}\right.$ between 0.48 and 0.69 ; $p<0.011$. I Ka exhibited a negative correlation with the kaolinite content of the soil $\left(R^{2}=-0.65 ; p<0.01\right)$, despite the positive correlation for wavelengths between $2200 \mathrm{~nm}$ and $2300 \mathrm{~nm}$ with the contents of this mineral $\left(R^{2}\right.$ between 0.58 and 0.66 ; $p<0.01$ I. $I_{\text {Gb }}$ exhibited a stronger negative correlation with goethite content $\left(R^{2}=-0.84 ; p<0.01\right)$ than with gibbsite content ( $R^{2}=-0.04$; not significant).

We observed that the effect of microaggregates on wavelengths between $401 \mathrm{~nm}$ and $2430 \mathrm{~nm}$ hindered but did not prevent the observation of the link between attributes of the spectra and soil. However, on the other hand, the link between microaggregates and spectra showed the potential of Vis-NIR spectra for discriminating soils according to their morphology.

\section{Discussion \\ Spectra related to soil structure}

Morphological characteristics of Ferralsol microaggregates examined in this study were not altered after the manual breakdown of the clumps and subsequent sieving through $2 \mathrm{~mm}$ mesh (as verified with a magnifying glass), which allows the effect of these microaggregates on the scattering of light and noise from the Vis-NIR spectra to be discussed. 

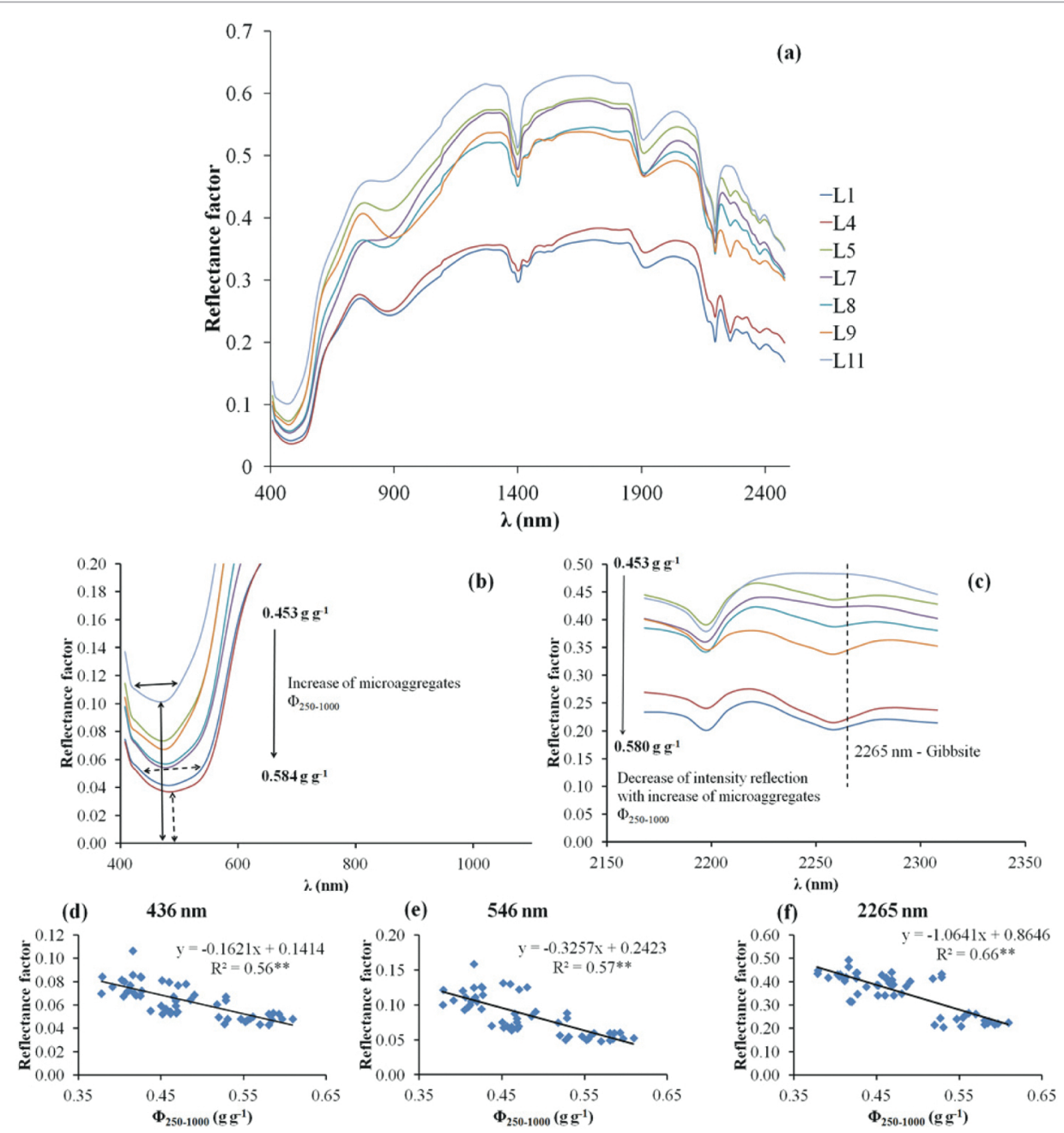

Figure 3. (a) Soil sample spectral mean reflectance from $400 \mathrm{~nm}$ to $2500 \mathrm{~nm}(0.875-0.925 \mathrm{~m}$ layer); (b) spectrum expansion at wavelengths between $400 \mathrm{~nm}$ and $770 \mathrm{~nm}$, indicating reflectance intensity and concavity according to microaggregates; (c) spectrum expansion at wavelengths between $2200 \mathrm{~nm}$ and $2300 \mathrm{~nm}$, indicating the reflectance intensity according to microaggregates. Linear regression between microaggregate size range $250-1000 \mu \mathrm{m}\left(\Phi_{250-1000}\right)$ and wavelengths (d) $436 \mathrm{~nm}$, (e) $546 \mathrm{~nm}$ and (f) $2265 \mathrm{~nm}$. In (b) the dashed line indicates wide spectral band with lower intensity of reflectance and the solid line indicates narrow spectral band with greater intensity of reflectance.

All wavelengths analysed were correlated with microaggregates of size in the range $250-1000 \mu \mathrm{m}$, except 650 and $700 \mathrm{~nm}$ (Table 3). The increased proportion of $\Phi_{250-1000}$ of these Ferralsols explained over $55 \%$ of the reflectance intensity variability of wavelengths $436 \mathrm{~nm}, 546 \mathrm{~nm}$ and $2236 \mathrm{~nm}$ and the reflectance intensity. The concavity of the spectra at these wavelengths decreased with an increased proportion of these microaggregates [Figure 3(d)-(f)].

These results can be explained by two effects of microaggregates on light reflection. The first effect is that the proportional mass increase of $\Phi_{250-1000}$ intensifies the scattering process of light, particularly at $436 \mathrm{~nm}$ and $546 \mathrm{~nm}$ in the visible region and at $2236 \mathrm{~nm}$ in the NIR [Figure 3(b), (d) and (e)]. In the NIR region, at $2200-2300 \mathrm{~nm}$, the scattering process caused by microaggregates is more pronounced in soils with porous massive structure (L1 and L4), with $\Phi_{250-1000}$ of more than $0.50 \mathrm{~g} \mathrm{~g}^{-1}$ soil [Figure $4(\mathrm{a})$ and (b)]. We interpreted this according to Sun et al. ${ }^{19}$ and Bänninger et al.. ${ }^{40}$ as the result of interdependence among particle size, specific surface area of microaggregates and scattering angle.

$\mathrm{L} 1$ and $\mathrm{L} 4$ soils with porous massive structure and predominance of $\Phi_{250-1000}$ (Table 2) showed higher $\mathrm{Fe}_{2} \mathrm{O}_{3}$ and $\mathrm{Al}_{2} \mathrm{O}_{3}$ content compared to soils with cohesive massive structure (Table 1), and soils with predominance of microaggregates and higher content of $\mathrm{Al}$ and Fe usually have larger specific surface areas. ${ }^{41}$

The second effect is that of micro-organisation of microaggregates on the processes of light absorption and reflectance. When photon energy enters a particle, in this case a microaggregate, some is reflected by the surface of the microaggregate, some passes through the microaggregate and some is absorbed. ${ }^{40,42}$ This process of reflection and/or absorption may be affected by the anisotropic reticular zones present in the microaggregates. Ferralsol microaggregates contain anisotropic reticular zones of approximately $800 \mu \mathrm{m},{ }^{43}$ which are increased by the interaction between organic matter and 
Table 3. Significant Pearson correlation coefficients of proportion of microaggregates predominant in the sample $\left(\Phi_{250-1000}\right)$ with spectral attributes $\left(R I_{\mathrm{CIE}}, I_{\mathrm{Ka}}\right.$ and $\left.I_{\mathrm{Gb}}\right)$ and wavelengths $(\mathrm{nm})$ of seven soil profiles $(n=56, p<0.05)$.

\begin{tabular}{|c|c|}
\hline & $\Phi_{250-1000}$ \\
\hline \multicolumn{2}{|c|}{ Spectral attributes } \\
\hline$R I_{\text {CIE }}$ & 0.88 \\
\hline$I_{\text {Ka }}$ & -0.82 \\
\hline$I_{G b}$ & -0.82 \\
\hline$I_{\mathrm{Ka}} /\left(I_{\mathrm{Ka}}+I_{\mathrm{Gb}}\right)$ & 0.77 \\
\hline \multicolumn{2}{|c|}{ Wavelengths } \\
\hline 401 & 0.57 \\
\hline 436 & 0.77 \\
\hline 440 & 0.72 \\
\hline 530 & 0.77 \\
\hline 546 & 0.80 \\
\hline 550 & 0.74 \\
\hline \multicolumn{2}{|l|}{650} \\
\hline \multicolumn{2}{|l|}{700} \\
\hline 845 & 0.56 \\
\hline 850 & 0.57 \\
\hline 870 & 0.59 \\
\hline 901 & 0.62 \\
\hline 931 & 0.62 \\
\hline 951 & 0.62 \\
\hline 1051 & 0.60 \\
\hline 1302 & 0.66 \\
\hline 1401 & 0.74 \\
\hline 1903 & 0.76 \\
\hline 2201 & 0.82 \\
\hline 2236 & 0.82 \\
\hline 2263 & 0.81 \\
\hline 2300 & 0.81 \\
\hline 2352 & 0.82 \\
\hline 2430 & 0.83 \\
\hline
\end{tabular}

iron and aluminium oxy-hydroxides. ${ }^{44}$ Thus, the interaction between the organic matter and iron and aluminium oxyhydroxide in the sample promotes an anisotropic environment within the microaggregate that increases the process of scattering light and noise, weakening the signal of the spectra at $436 \mathrm{~nm}, 546 \mathrm{~nm}$ and $2236 \mathrm{~nm}$ with increase of $\Phi_{250-1000}$.

On another scale of microaggregate analysis, the interaction between organic matter and iron and aluminium oxyhydroxides may increase the scattering light for spectra of soil with porous massive structure because this interaction causes a disorganisation in the arrangement (stacking) of the minerals, primarily by the following two mechanisms: (i) binding to the surface of other minerals by their edges, promoting a disorganised stacking of kaolinite, $43,45,46$ and (ii)
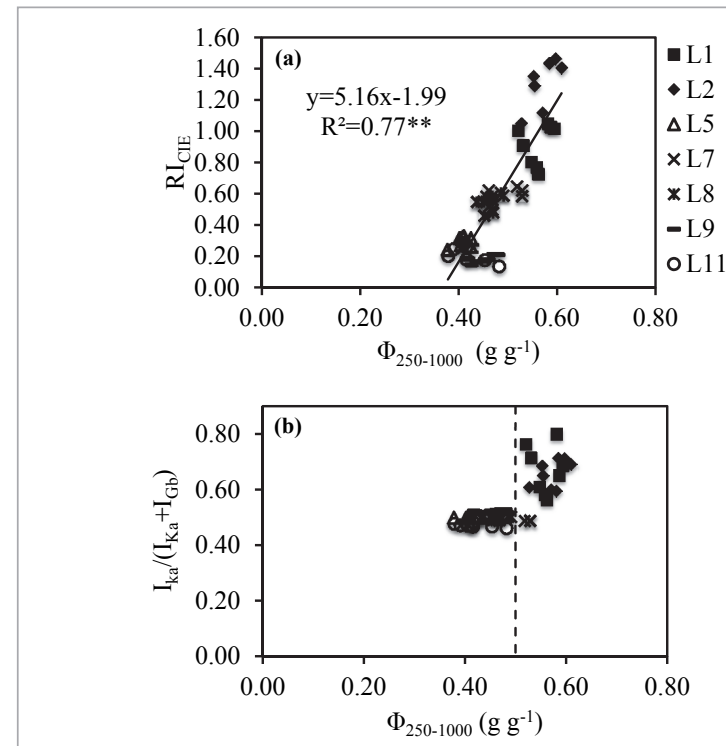

Figure 4. Absorption intensity of (a) red index and (b) kaolinite and gibbsite ratio of spectral samples according to proportion of microagregates $\Phi_{250-1000}(n=56)$.

the iron acting as a polycationic ligand for other molecules in the composition and internal organisation of microaggregates, this same concept also applying to gibbsite. ${ }^{45}$ In this way, the porosity formed by a disorganisation in the arrangement of the primary minerals results in increased specific surface area and anisotropic reticular zones, increasing the probability of light being absorbed in internal microaggregate pores, as observed by Bänninger et al. ${ }^{40}$

Thus, with our soil sample collection, sieving of the samples did not prevent the different reflectance intensity of light and or concavity of the spectra, inherent to soils with porous and cohesive macromorphological features.

These results highlight the potential use of Vis-NIR spectroscopy in analyses of soil structure. In addition, given the inversely proportional relationship of microaggregates with soil density, we can suggest another way of analysing the structure and density of soils, directly from the spectra without the need for predictive models.

\section{Soil morphology evaluation by spectral attributes}

Spectral attributes were correlated with Ferralsol morphology. Absorption intensities of $R I_{\mathrm{CIE}}$ were distinct from the intensities of massive cohesive structure soils [Table 2 and Figure $4(a)]$ and samples of $L 1$ and L4 soils exhibited greater variability in the kaolinite and gibbsite absorption ratio [Figure $4(b)]$ in the region $2200-2300 \mathrm{~nm}$, emphasising the effect of surface roughness and of the organisation of minerals within the microaggregates, as mentioned above. Therefore, analysis of the effect of microaggregates on spectra can be performed for samples sieved through a $2.00 \mathrm{~mm}$ mesh using spectral attributes.

The relationship between $R /_{\text {CIE }}$ and the proportion of $\Phi_{250-}$ 1000 . which is associated with the disorganisation of minerals, 
favoured the distinction of Ferralsols because the reflection provided by the relationship between these attributes was inherent for the nature of macrostructures of those soils [Figure $4(a)]$. These results are consistent with those of Huete and Escadafal ${ }^{47}$ and Bänninger et al., ${ }^{40,48}$ who reported that the absorption intensity and spectral composition of reflected energy may be used to describe the optical behaviour of soil due to the influence of its chemical and mineralogical composition and of the size, distribution and arrangement of microaggregates.

Notably, relationships between $R /_{\text {CIE }}$ and the proportion of $\Phi_{250-1000}$ overlapped the relationship of this spectral attribute with hematite contents. This microaggregate class accounts for over $75 \%$ of $R I_{\text {CIE }}$ variability in soils. Furthermore, cohesive massive structure soils such as $L 9$ soil $\left(27.35 \mathrm{~g} \mathrm{~kg}^{-1}\right.$ hematite) exhibited lower R/CIE absorption intensities than L5, L7, L8 and L11 soils (maximum hematite content of $12.57 \mathrm{~g} \mathrm{~kg}^{-1}$ ) (Tables 1 and 2). Thus, the effect of size and roughness of microaggregates present in a sample on the spectra mentioned by White and Roth, ${ }^{1}$ Escadafal et al., ${ }^{17}$ Escadafal ${ }^{48}$ and Wu et al. ${ }^{18}$ may be evaluated by the $\Phi$ parameter for Ferralsols and should be further studied for other types of soils.

Another important factor of the influence of microaggregates on the spectra is that the predominance of $\Phi_{250-1000}$ and the disorganisation of minerals may have a negative effect on the construction of predictive models because although these minerals do not prevent observation, these factors hinder the observation of correlations between spectral $\left(R /_{\text {CIE }} I_{\text {Ka }}\right.$ and $\left.I_{\text {Gb }}\right)$ and soil (hematite, goethite, gibbsite and kaolinite content) attributes. Thus, the more pronounced the strong granular and very thin structure of microaggregates, the greater the noise in the spectra, and consequently the greater the variability of the spectra of these soils is likely to be. Chang et al. ${ }^{20}$ Brunet et al. ${ }^{50}$ and Wu et al. ${ }^{18}$ also reported that increasing the roughness of soil samples promoted an increase in noise in the spectra.

Increased noise in the spectra, promoted by the proportion of microaggregates in a soil sample and by the stacking porosity of goethite and gibbsite minerals, may partially explain the weak correlation observed between pure and soil minerals ${ }^{37}$ and the coefficients below 0.6 in the construction of models to predict iron oxides. ${ }^{51}$

\section{Using $\Phi$ and the soil spectra}

Using samples of clayey Ferralsols, Volland-Tuduri et al. ${ }^{34}$ developed the equation $\Phi_{<0.84}=1.97$ (1/bulk density) -1.52 , which relates inverse bulk density to the proportion of microaggregates with diameter $<840 \mu \mathrm{m}\left(\Phi_{<840}\right)$. Thus, we evaluated the effects of microaggregates on the spectra using the $\Phi_{<840}$ equation that represents the relationship between microaggregates and bulk density of other Ferralsols but in a pedologically and geomorphologically similar situation to this study.

The variation of $R I_{\mathrm{CIE}}$ and kaolinite and gibbsite ratio using the prediction results for $\Phi_{<840}$ was similar to that observed in this study when the proportion of $\Phi_{250-1000}$ was determined.

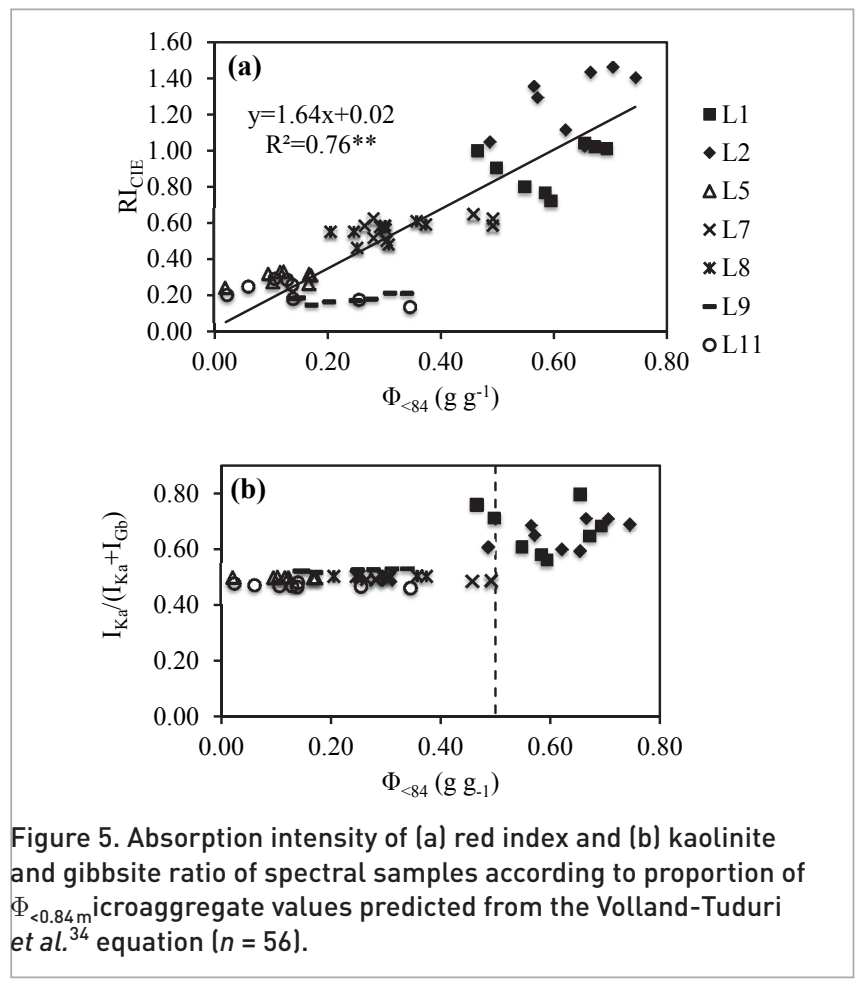

Results obtained from the equation proposed by VollandTuduri et al. ${ }^{34}$ were similar to the results obtained in the present study, despite the different classes of aggregates used. The difference in $R I_{\mathrm{CIE}}$ variation range and absorption intensity of gibbsite when kaolinite was constant could be observed according to the increased proportion of $\Phi_{<840}$ in the soil sample, particularly when this proportion was more than $0.50 \mathrm{~g} \mathrm{~g}^{-1}$ of soil microaggregates (Figure 5). This result confirmed the differences between the $\Phi_{250-1000}$ values of the porous massive structure and cohesive massive structure soils measured in this study (Table 2) and highlighted that the relationship between $\Phi$ and spectral attributes, $R I_{\text {CIE }}$ and reflectance intensity of kaolinite and gibbsite content, may be extrapolated to other landscapes with Ferralsols whose characteristics are similar to those of this study.

The differences in $I_{K a}$ and $I_{G b}$ ratio between $\Phi_{250-1000}$ and $\Phi_{<840}$ when the proportion of microaggregates was less than $0.50 \mathrm{~g} \mathrm{~g}^{-1}$ of soil sample [Figures $4(\mathrm{~b})$ and $5(\mathrm{~b})$ ] were due to the effect of the fine sand fraction of the samples. For our collection of samples, fractions smaller than $250 \mu \mathrm{m}$ were related to the fine sand fraction $\left(R^{2}=0.70, p<0.01\right)$, which was composed of pseudo sand particles (microaggregates not dispersed during the analytical procedures with $\mathrm{NaOH})^{52}$ and of quartz, particularly for profiles with medium clayey texture, which was a texture not included in the Volland-Tuduri et al. ${ }^{34}$ model.

\section{Conclusions}

Ferralsols with various macromorphological structures were characterised using the proportion of predominant soil 
microaggregate mass $(\Phi)$. The predominant microaggregate diameter of these soils ranged between $250 \mu \mathrm{m}$ and $1000 \mu \mathrm{m}$ $\left(\Phi_{250-1000}\right)$.

The results of this study allowed the millimetre- and micrometre-scale observation of the effect of the presence of aggregates with various sizes and composition on the spectra. The more pronounced the morphological porous massive structure with a strong granular and very thin structure of microaggregates, the greater the scattering and variability of the spectra of these soils. The microaggregate size explained over $55 \%$ of reflectance intensity variability of the wavelengths in the visible and NIR regions, principally of the reflectance intensity and the concavity of the spectra at $436 \mathrm{~nm}, 546 \mathrm{~nm}$ and $2236 \mathrm{~nm}$ that decreased with the increased proportion of $\Phi_{250-1000}$.

The $2 \mathrm{~mm}$ sieving of soil samples did not prevent the different reflectance intensity of light and or concavity of the spectra, which are different for soils with porous and cohesive morphological structures.

The CIE red index and the absorption intensity of kaolinite and gibbsite obtained from the Vis-NIR spectra can be used to characterise the morphological differences between Ferralsols. As well as spectra, the discrimination of Ferralsols can be performed through the spectral red index and absorption intensity of kaolinite and gibbsite, given the significant linear relationship between microaggregates and $R /_{\text {CIE }}$ and the difference in variability of $I_{\mathrm{Ka}}$ and $I_{\mathrm{Gb}}$ ratio according to soil structures.

\section{Acknowledgements}

We thank the CAPES for its financial support of J.F. Oliveira's work in France. This research is part of the project CAPES/ Brasil-COFECUB/France (Spectrosol) no. Te 823-14/.

\section{Conflict of interest}

The authors have no conflicts of interest to declare.

\section{References}

1. J.L. White and C.B. Roth, "Infrared spectroscopy", in Methods of Soil Analysis, Part I: Physical and Mineralogical Methods, Ed by G.S. Campbell, R.D. Jackson, M.M. Mortland, D.R. Nielsen and A. Klute. American Society of Agronomy, Soil Science Society of America, Madison, WI, pp. 291-326 (1986).

2. C. Pasquini, "Near infrared spectroscopy: fundamentals, practical aspects and analytical applications", J. Brazilian Chem. Soc. 14, 198 (2003). doi: http://dx.doi. org/10.1590/S0103-50532003000200006

3. B. Stenberg, R.A. Viscarra Rossel, A.M. Mouazen and J. Wetterlind, "Visible and near infrared spectroscopy in soil science", in Advances in Agronomy, Ed by D.L. Sparks. Academic Press, Burlington, MA, pp. 163-215 (2010).

4. K.H. Norris and J.R. Hart, "Direct spectrophotometric determination of moisture content of grain and seeds", in Proceedings of the 1963 International Symposium on Humidity and Moisture, New York, pp. 19-25 (1965).

5. I. Ben-Gera and K.H. Norris, "Direct spectrophotometric determination of fat and moisture in meat products", J. Food Sci. 33, 64 (1968). doi: http://dx.doi. org/10.1111/j.1365-2621.1968.tb00885.x

6. WRB, World Reference Base for Soil Resources. FAO, Rome (2006).

7. H.G. Santos, P.K.T. Jacomine, L.H.C. Anjos, V.A. Oliveira, J.B. Oliveira, M.R. Coelho, J.F. Lumbrelas and T.J.F. Cunhas, Sistema Brasileiro de Classificação de Solos. Centro Nacional de Pesquisa de Solos, Rio de Janeiro (2006).

8. H. Neufeldt, M.A. Ayarza, D.V.S. Resck and W. Zech, "Distribution of water-stable aggregates and aggregating agents in Cerrado Oxisols", Geoderma 93, 85 (1999). doi: http://dx.doi.org/10.1016/S0016-7061(99)00046-4

9. R. Westerhof, P. Buurman, C. van Griethuysen, M. Ayarza, L. Vilela and W. Zech, “Aggregation studied by diffraction in relation to plowing and liming in the Cerrado region in Brazil", Geoderma 90, 277 (1999). doi: http://dx.doi.org/10.1016/S0016-7061(98)00133-5

10. M.L. Kubiena, "Zur micromorphologie der braunen und roten tropenboden", in Transactions of the 4th International Congress of Soil Science, Vol. 1, pp. 304-307 (1950).

11. R. Brewer, Fabric and Mineral Analysis of Soils. Wiley, New York (1964).

12. C.G. Trapnell, R. Webster and P.R. Hesse,

"Microaggregates in red earths and related soils in East and Central Africa, their classification and occurrence", J. Soil Sci. 37, 109 (1986). doi: http://dx.doi. org/10.1111/j.1365-2389.1986.tb00012.x

13. L.C. Balbino, A. Bruand, M. Brossard, M. Grimaldi, M. Hajnos and M.F. Guimarães, "Changes in porosity and microaggregation in clayey Ferralsols of the Brazilian Cerrado", Eur. J. Soil Sci. 53, 219 (2002). doi: http://dx.doi. org/10.1046/j.1365-2389.2002.00446.x

14. M.M. Ferreira, B. Fernandes and N. Curi, "Mineralogia da Fração Argila e Estrutura de Latossolos da Região Sudeste do Brasil", Revista Brasileira de Ciência do Solo 23, 507 (1999)

15. N. Volland-Tuduri, "Nature et mode d'assemblage des constituants minéraux et organiques dans des Ferralsols de la région des cerrados (Brésil): evolution après mise en culture", PhD thesis, Université D’Orléans (2005).

16. L.C. Balbino, M. Brossard, J.-C. Leprun and A. Bruand, “Mise en valeur des Ferralsols de la Région du Cerrado (Brésil) et évolution de leurs propriétés physiques: une étude bibliographique", Étude et Gestion des Sols 9, 83 (2002). 
17. R. Escadafal, C. Gouinaud, R. Mathieu and M. Pouget, "Le spectroradiomètre de terrain: un outil de la télédétection et de la pédologie", Cahiers Orstom, série Pédologie 28, 15 (1993).

18. C.Y. Wu, A.R. Jacobson, M. Laba and P.C. Baveye, "Accounting for surface roughness effects in the near infrared reflectance sensing of soils", Geoderma 152, 171 (2009). doi: http://dx.doi.org/10.1016/i. geoderma.2009.06.002

19. Z. Sun, J.Z.Z. Tong and Y. Zhao, "Particle size effects on the reflectance and negative polarization of light backscattered from natural surface particulate medium: soil and sand", J. Quant. Spectrosc. Radiat. Transf. 133, 1 (2014). doi: http://dx.doi.org/10.1016/j. jqsrt.2013.03.013

20. C.W. Chang, D.A. Laird, M.J. Mausbach and C.R. Hurburgh Jr, "Near-infrared reflectance spectroscopy - principal components regression analyses of soil properties", Soil Sci. Soc. Am. J. 65, 480 (2001). doi: http://dx.doi.org/10.2136/sssaj2001.652480x

21. S. Chamizo, A. Stevens, Y. Cantón, I. Miralles, F. Domingo and B. Van Wesemael, “Discriminating soil crust type, development stage and degree of disturbance in semiarid environments from their spectral characteristics", Eur. J. Soil Sci. 63, 42 (2012). doi: http://dx.doi.org/10.1111/j.1365-2389.2011.01406.x

22. H. Croft, K. Anderson and N.J. Kuhn, "Reflectance anisotropy for measuring soil surface roughness of multiple soil types", Catena 93, 87 (2012). doi: http:// dx.doi.org/10.1016/j.catena.2012.01.007

23. P. Jouquet, T. Henry-des-Tureaux, J. Mathieu, T.D. Thu, T.T. Duc and D. Orange, "Utilization of near infrared reflectance spectroscopy (NIRS) to quantify the impact of earthworms on soil and carbon erosion in steep slope ecosystem: a study case in northern Vietnam", Catena 81, 113 (2010). doi: http://dx.doi.org/10.1016/j. catena. 2010.01 .010

24. J. Torrent, U. Schwertmann, H. Fechter and F. Alferez, "Quantitative relationships between soil color and hematite content", Soil Sci. 136, 354 (1983). doi: http:// dx.doi.org/10.1097/00010694-198312000-00004

25. J.S. Madeira Netto, A. Bedidi, B. Cervelle, M. Pouget and N. Flay, "Visible spectrometric indices of hematite $(\mathrm{Hm})$ and goethite $(G \mathrm{t})$ content in lateritic soils: the application of a thematic mapper (TM) image for soil-mapping in Brasilia, Brazil", Int. J. Remote Sens. 18, 2835 (1997). doi: http://dx.doi.org/10.1080/014311697217369

26. Z. Szalai, K. Kiss, G. Jakab, P. Sipos, B. Belucz and T. Németh, "The use of UV-VIS-NIR reflectance spectroscopy to identify iron minerals", Astron. Nachr. 334, 940 (2013). doi: http://dx.doi.org/10.1002/asna.201211965

27. R.D. Santos, R.C. Lemos, H.G. Santos, J.C. Ker and L.H.C. Anjos, Manual de Descrição e Coleta de Solo No Campo. Sociedade Brasileira de Ciência do Solo, Viçosa (2005).

28. Munsell Soil Color Charts. Munsell Color Company, Baltimore, MD (1975).
29. J.F. Oliveira, M. Brossard, P.R.S. Vendrame, S. Mayi III, E.J. Corazza, R.L. Marchão and M.F. Guimarães, "Soil discrimination using diffuse reflectance Vis-NIR spectroscopy in a local toposequence", C. R. Geosci. 345, 446 (2013). doi: http://dx.doi.org/10.1016/j.crte.2013.12.001

30. G.K. Donagema, D.V.B. Campos, S.B. Calderano, W.G. Teixeira and J.H.M. Viana, Manual de Métodos de Análise de Solos. Embrapa Solos, Rio de Janeiro (2011).

31. M. Resende, A.F.C. Bahia Filho and J.M. Braga, "Mineralogia da argila de latossolos estimada por alocação a partir do teor total de óxidos do ataque sulfúrico", Revista Brasileira de Ciência do Solo 11, 17 (1987).

32. U. Schwertmann and R.M. Taylor, "Iron oxides", in Minerals in Soil Environments, Ed by J.B. Dixon and S.B. Weed. Soil Science Society of America, Madison, WI, pp. 379-438 (1989).

33. M. Resende and D.P. Santana, "Uso das relações Ki e Kr na estimativa da mineralogia para classificação dos latossolos", in Anais da 3 Reunião de Classificação, Correlação de Solos e Interpretação de Aptidão Agrícola. EMBRAPA-SNLCS/SECS, Rio de Janeiro, pp. 225-229 (1988).

34. N. Volland-Tuduri, A. Bruand, M. Brossard, L.C. Balbino, M.I.L. Oliveira and E.S. Martins, "Mass proportion of microaggregates and bulk density in a Brazilian clayey Oxisol", Soil Sci. Soc. Am. J. 69, 1559 (2005). doi: http:// dx.doi.org/10.2136/sssaj2003.0344

35. J.S. Madeira Netto, Étude Quantitative des Relations Constituants Minéralogiques - Réflectance Diffuse des Latosols Brésiliens: Application à l'Utilisation Pédolocique des Données Satellitaires TM (Région de Brasilia). Université Pierre et Marie Curie (Paris VI) (1993).

36. J.S. Madeira Netto, A. Bédidi, M. Pouget, B. Cervelle and N. Flay, "Spectral (MIR) determination of kaolinite and gibbsite contents in lateritic soils", C. R. Acad. Sci. 321, 119 (1995). doi: http://dx.doi.org/1250-8050/95/03210119

37. R.A. Viscarra Rossel, R.N. Mcglynn and A.B. McBratney, "Determining the composition of mineral-organic mixes using UV-vis-NIR diffuse reflectance spectroscopy", Geoderma 137, 70 (2006). doi: http://dx.doi.org/10.1016/j. geoderma.2006.07.004

38. J.A.M. Demattê and F.S. Terra, "Spectral pedology: a new perspective on evaluation of soils along pedogenetic alterations", Geoderma 217-218, 190 (2014). doi: http:// dx.doi.org/10.1016/j.geoderma.2013.11.012

39. P. Dalgaard, "Analysis of variance and the KruskalWallis test", in Statistics in Computing, Springer, pp. 127-143 (2008). doi: http://dx.doi.org/10.1007/978-0-38779054-1 7

40 D. Bänninger, P. Lehmann and H. Flühler, “Modelling the effect of particle size, shape and orientation of light transfer through porous media", Eur. J. Soil Sci. 57, 906 (2006). doi: http://dx.doi.org/10.1111/j.13652389.2005.00787.x 
41. C. Feller, E. Schouller, F. Thomas, J. Rouiller and A.J. Herbillon, "N2-BET specific surface areas of some low activity clay soils and their relationships with secondary constituents and organic matter contents", Soil Sci. 153, 293 (1992).

42. R.N. Clark, "Reflectance spectra", in Handbook of Physical Constants. American Geophysical Union, Washington, DC, pp. 178-188 (1995).

43. G. Vrdoljak and G. Sposito, "Soil aggregate hierarchy in a Brazilian Oxisol", in Developments in Soil Science, Ed by A. Violante, P.M. Huang, J.-M. Bollag and L. Gianfreda. Elsevier Science, New York, pp. 197-217 (2002).

44. L. Gargiulo, G. Mele and F. Terribile, "Image analysis and soil micromorphology applied to study physical mechanisms of soil pore development: an experiment using iron oxides and calcium carbonate", Geoderma 197-198, 151 (2013). doi: http://dx.doi.org/10.1016/j. geoderma.2013.01.008

45. E. Camacho, M. Robert and A.M. Jaunet, "Mineralogy and structural organization of a red to yellow soil sequence in Cuba. Relationship with soil properties", in Proceedings of the VIIth International Working Meeting on Soil Micromorphology, Paris, pp. 183-190 (1987).

46. O. Rozenbaum, A. Bruand and E.L. Trong, "Soil porosity resulting from the assemblage of silt grains with a clay phase: new perspectives related to utilization of $X$-ray synchrotron computed microtomography", C. R. Geosci. 344, 516 (2012). doi: http://dx.doi.org/10.1016/j. crte.2012.09.004
47. A.R. Huete and R. Escadafal, “Assessment of biophysical soil properties through spectral decomposition techniques", Remote Sens. Environ. 35, 149 (1991). doi: http://dx.doi.org/10.1016/0034-4257(91)90008-T

48. D. Bänninger and H. Flühler, "Modeling light scattering at soil surfaces", IEEE Trans. Geosci. Remote Sens. 42, 1462 (2004). doi: http://dx.doi.org/10.1109/ TGRS.2004.828190

49. R. Escadafal, "Remote sensing of arid soil surface color with Landsat thematic mapper", Adv. Space Res. 9, 159 (1989). doi: http://dx.doi. org/10.1016/0273-1177(89)90481-X

50. D. Brunet, B.G. Barthès, J.-L. Chotte and C. Feller, "Determination of carbon and nitrogen contents in Alfisols, Oxisols and Ultisols from Africa and Brazil using NIRS analysis: effects of sample grinding and set heterogeneity", Geoderma 139, 106 (2007). doi: http:// dx.doi.org/10.1016/j.geoderma.2007.01.007

51. P.R.S. Vendrame, R.L. Marchão, D. Brunet and T. Becquer, "The potential of NIR spectroscopy to predict soil texture and mineralogy in Cerrado Latosols", Eur. J. Soil Sci. 63, 743 (2012). doi: http://dx.doi.org/10.1111/ j.1365-2389.2012.01483.x

52. J.B.V. Gomes, N. Curi, D.G. Schulze, J.J.G.S.M. Marques, J.C. Ker and P.E.F. Motta, "Mineralogia, morfologia e análise microscópica de solos do bioma cerrado", Revista Brasileira de Ciência do Solo 28, 679 (2004). 